\title{
Evalvacija zaznavno-motoričnih sposobnosti za ugotavljanje učinkovitega vedenja v varnostno zahtevnih situacijah
}

\author{
Klinični inštitut za medicino dela, prometa in športa, Univerz
}

Povzetek: Ustrezno in učinkovito vedenje delavcev v varnostno zahtevnih delovnih situacijah je ključno za zagotavljanje varnosti pri delu. Delovna mesta, pri katerih so zaznavno-motorične obremenitve ocenjene kot višje od povprečja, zahtevajo ustrezno boljše psihomotorične sposobnosti delavca. Zmožnost osebe za opravljanje dela v okolju s povečanimi obremenitvami in tveganji se ocenjuje v okviru psihološkega pregleda za oceno delazmožnosti. V prispevku so predstavljeni rezultati raziskave izvedene na vzorcu 198 kandidatov in zaposlenih na delovnih mestih s področja prvih posredovalcev, zdravstva, varnostne dejavnosti in redarstva. Psihomotorične sposobnosti udeležencev smo ocenili s preizkušnjami orientacije v polju, vidno motorične koordinacije in diferenciranega motoričnega odzivanja. Analizirali smo temeljne značilnosti motoričnega odreagiranja glede na način predvajanja dražljajev v preizkušnji (aktivni in adaptivni), vrsto motorične aktivnosti (diskretne in kontinuirane) in razmerje med odzivi in dražljaji. Rezultati kažejo, da so osebe s hitrejšimi odzivnimi časi učinkovitejše pri izvajanju diskretnih motoričnih nalog. Za učinkovito izvajanje kontinuiranih motoričnih nalog je potrebna ustrezna uravnoteženost psihomotorične funkcije, ki se določi skozi razmerje med hitrostjo in natančnostjo odzivov. Med udeleženci so statistično pomembne razlike v sposobnosti ohranjanja natančnosti pod časovno obremenitvijo in kažejo značilnosti stila psihomotornega odzivanja, ki favorizira hitrost ali natančnost motoričnega odgovora. Glede na rezultate sama ocena hitrosti in natančnosti motoričnega odreagiranja ne zadošča za celovito oceno psihomotorične zmožnosti. Pri oceni zmožnosti za opravljanje dela s povečanim varnostnim tveganjem je potrebno upoštevati tudi razmerje med hitrostjo in natančnostjo ter sposobnost ohranjanja motoričnih odzivov pod časovno obremenitvijo.

Ključne besede: ocena delazmožnosti, zahtevne delovne situacije, zaznavno-motorične sposobnosti, odzivni čas, učinkovitost vedenja

\section{Evaluation of visual motor skills to determine effective behaviour in demanding work situations}

\author{
Matej Čeh* and Marija Molan
}

Institute of Occupational, Traffic and Sports Medicine, University Medical Center Ljubljana, Slovenia

\begin{abstract}
A person's ability to behave effectively in demanding work situations at work is evaluated as part of a psychological assessment of work ability. Workplaces, where the visual and motor skill loads are assessed as above average, adequate psychomotor skills of the worker are required. In this paper we present the results of a research performed on a sample of 198 candidates and employees in workplaces from the fields of first response, health, safety, and security. We evaluated the psychomotor abilities of the individuals included in the research by using tests of visual orientation, visual motor coordination, and differentiated motor responsiveness. The results were compared according to the way stimuli were presented (active or adaptive), the type of motor activity (discrete or continuous), and the responses/stimuli ratio. Analysis shows that individuals with faster responses are more effective with discrete motor tasks. To perform continuous motor tasks under time pressure, the individual must have adequate balance of psychomotor functions, which is determined with the speed and accuracy ratio response. The analysis shows that there are statistically significant differences in the ability of participants to keep accurate responses under time pressure. These differences show the psychomotor response style that either favours speed or accuracy. We conclude that the speed and accuracy of motor reactions is not sufficient to provide a comprehensive assessment of the psychomotor capability. When evaluating the ability to perform adequately in work with higher risk conditions it is necessary to consider the ratio between speed and accuracy, as well as the capability of maintaining adequate motor reactions under time pressure.
\end{abstract}

Keywords: work ability assessment, demanding work situations, visual motor skills, response time, behavioral efficiency

\footnotetext{
"Naslov/Address: Matej Čeh, Klinični inštitut za medicino dela, prometa in športa, Univerzitetni klinični center Ljubljana, Grablovičeva ulica 42, 1000 Ljubljana, e-mail: matej.ceh@kclj.si 
Usklajenost zmožnosti delavca in zahtev dela je temelj, ki lahko zagotovi dobro počutje in ustrezno razpoložljivost. Predvsem v dejavnostih, ki so zelo nepredvidljive in spreminjajoče, ni mogoče le s posegi v delovno okolje zagotoviti usklajenosti dela in delavca ter ustrezne ravni varnosti. Zato je za učinkovito vedenje $\mathrm{v}$ teh okoljih pomembno ujemanje fizioloških in psiholoških značilnosti osebe $\mathrm{z}$ naravo dela in z zmožnostjo delavca (Molan in Arnerič, 2000).

\section{Psihosocialna tveganja v delovnem okolju}

Psihosocialne značilnosti delovnega okolja obsegajo psihološke in socialne pojave. Značilna psihosocialna tveganja izhajajo iz vsebine dela, delovne intenzitete in avtonomije, delovnega časa ter zagotavljanja ravnotežja med delovnim in prostim časom (Eurofound in EU-OSHA, 2014). Nekatere skupine delavcev so izpostavljene večjim tveganjem na delovnem mestu (EU-OSHA, 2009), kot so npr. delo pod časovnimi pritiski, monotona ali vsebinsko zelo zahtevna dela in opravljanje del $\mathrm{z}$ zmanjšanim nadzorom nad delom (Cox in Griffiths, 2005). Zahteve dela povzročajo fizične in kognitivne obremenitve zaradi vsebine, hitrosti in obsega dela (EU-OSHA, 2009). Indeks intenzivnosti dela določajo tri spremenljivke: visoka hitrost opravljanja dela, pomanjkanje časa za dokončanje dela in predvideni kratki roki za izdelavo (Eurofound in EU-OSHA, 2014). Obremenitve in posledično zahteve delovnega mesta so opredeljene v oceni tveganja. To je dokument, na osnovi katerega so prepoznane tiste lastnosti, ki so za varno in učinkovito delo najpomembnejše (Molan in Molan, 2008). Osnovni namen izdelave ocene tveganja je obvladovanje tveganj $\mathrm{v}$ delovnem okolju. Po zakonodaji o varnosti in zdravju pri delu je v okviru izjave o varnosti pri delu obveza delodajalca (Zakon o varnosti in zdravju pri delu, 2011). Negativni stresni odzivi se pri delavcu pojavijo, kadar zahteve delovnega okolja presegajo njegove sposobnosti. Razhajanje se kaže skozi oteženo izpolnjevanje in obvladovanje delovnih nalog (Karasek, 1979; Karasek in Theorell, 1990). Pomemben vpliv na doživljanje stresa in obremenitev imajo individualne razlike med posamezniki, njihove značilnosti in načini soočanja $\mathrm{z}$ obremenitvami pri delu (EU-OSHA, 2009).

Po modelu regulativnega nadzora (Hockey, 1997) je vzdrževanje stabilnosti funkcioniranja pod visokimi obremenitvami in $\mathrm{v}$ stresnih okoljih individualno nadzorovan proces posameznika. Upravljanje s kognitivnimi viri omogoča osebi, da v takšnih okoljih uporablja strategije za zaščito učinkovitega vedenja. Model razlikuje med dvema ravnema nadzora. Prva, nižja raven, je povezana $\mathrm{z}$ rutinskim nadzorom. Na tej ravni je nadzor avtomatiziran in ne zahteva mobilizacije dodatnih psihičnih naporov. Druga, višja raven nadzora, je potrebna, kadar se pojavi potreba po ohranjanju stabilnosti funkcioniranja in proces nadzora na nižji ravni ne omogoča zadostne učinkovitosti vedenja. Teorija regulativnega nadzora daje širšo teoretsko podlago za razlago učinkovitosti vedenja pod vplivi dejavnikov okolja, kot sta stres in delovna obremenjenost. Uporaba kompenzacijskih mehanizmov predstavlja osrednji del sistemske regulacije kognitivnih ciljev in napora. Pri analizi učinkovitosti vedenja in vpliva okoljskih dejavnikov je zato pomembno, da poleg primarne obremenitve, ki predstavlja izvajanje same naloge, upoštevamo tudi vpliv sekundarnih dejavnikov in posledice (t.i. stroške) regulativne dejavnosti. Vzdrževanje učinkovitega vedenja pod stresom in visokimi obremenitvami zahteva povečan psihični napor. Kaže se skozi zanemarjanje podrejenih ciljev oz. dejavnosti in $\mathrm{v}$ zožitvi pozornosti. Kot posledica povečanega psihičnega napora se pojavi težnja po uporabi enostavnejših izvršilnih strategij, ki so za delovni spomin in vzdrževanje učinkovitega vedenja manj obremenjujoče. Oseba doživlja občutke subjektivne utrujenosti in je bolj nagnjena $\mathrm{k}$ sprejemanju rizičnih odločitev.

\section{Zaznavno-motorične sposobnosti in delazmožnost}

V delovnih okoljih so lahko delavci izpostavljeni varnostno zahtevnim situacijam zaradi zahtev po hitrosti, natančnosti in raznovrstnosti zaznavanja informacij ter motoričnega odreagiranja. Takšne obremenitve $\mathrm{v}$ realnem delovnem okolju predstavljajo npr. delo pod časovnimi pritiski in zahteve po nenadnem ukrepanju, delo z nevarnimi in občutljivimi snovmi in opremo ter delo $\mathrm{v}$ senzorno zahtevnih okoljih (Molan in Molan, 2008). Neprilagojeno vedenje delavca $v$ takšnem okolju ogroža njegovo varnost, varnost drugih ali okolja (Molan in Arnerič, 2000; Molan in Molan, 2008).

Že na preventivni ravni, $\mathrm{v}$ okviru predhodnega psihološkega pregleda, je potrebno izvajati aktivnosti, ki omogočajo ohranjanje varnosti in zdravja delavcev (Molan in Arnerič, 2000). Pri ocenjevanju zmožnosti za izvajanje kompleksnih delovnih aktivnosti je potrebno uporabiti nabor psihodiagnostičnih postopkov, ki zagotavljajo oceno vseh relevantnih lastnosti, katere vplivajo na izvajanje aktivnosti (Vetter idr., 2015). Delovna mesta, pri katerih so zaznavno-motorične obremenitve ocenjene kot višje od povprečja, zahtevajo ustrezne zaznavne, kognitivne in motorične sposobnosti. Takšna ocena delazmožnosti obsega celoto zaznavnih in izvršilnih procesov, pozornosti in senzomotorične sposobnosti (Molan in Arnerič, 2000; Molan in Molan, 2008). Te sposobnosti so nepogrešljive za uspešno izvajanje kompleksnih psihomotoričnih nalog, kot je npr. vožnja avtomobila (Sommer idr., 2010; Zabukovec, 2007) ter $\mathrm{v}$ povezavi s časovnimi in gibalnimi zahtevami predstavljajo pomemben del celovite psihomotorične aktivnosti (Mańkowska idr., 2015).

Motorična aktivnost je kompleksna lastnost, ki jo ocenjujemo z merami natančnosti, preciznosti, hitrosti, moči, fleksibilnosti, ravnotežja, konsistentnosti in vzdržljivosti (Hill idr., 2018). Zmožnosti motoričnega odreagiranja se kažejo v izvedbi motorične aktivnosti glede na dražljajsko situacijo in okolje. Diskretna motorična aktivnost je nenadna in običajno zahteva hitro izvedbo, začetek in konec motorične akcije sta poznana. Za kontinuirane motorične aktivnosti je značilno, da začetek in konec aktivnosti nista prepoznana, aktivnost se izvaja dokler ni prekinjena. $\mathrm{V}$ primerjavi z diskretno motorično aktivnostjo, kontinuirana aktivnost običajno traja daljši čas in zahteva neprestano prilagajanje motoričnih akcij glede na spremembe v okolju (Schmidt, 1988). 
Sposobnost koordiniranja gibov nam omogoča ustvarjanje gibalnih vzorcev. Koordiniranje motoričnih odzivov je usklajevanje motoričnih gibov glede na čas, prostor in stopnjo naprezanja. Kaže se v uspešnosti posameznika, da oblikuje določene gibalne strukture, glede na dražljajske zahteve v okolju (Greene in Williams, 1996). Poznamo dve vrsti koordinacije motoričnih vzorcev in veščin glede na tehnike različnih gibanj. Splošna koordinacija usklajuje osnovne gibalne vzorce in tehnike. Specifična koordinacija je značilna za točno določeno aktivnost oz. gibalno nalogo. Sposobnost vidno motoričnega koordiniranja omogoča skladno in usklajeno motorično aktivnost na relacij oko-roka/ noga. Določata jo hitrost in natančnost izvedbe. Fleksibilnost se kaže $\mathrm{v}$ sposobnosti prilagoditve gibalnega vzorca na spremembe dražljajske situacije (Škof, 2019).

$\mathrm{V}$ realnih delovnih okoljih večina aktivnosti zahteva kombinacijo in povezanost raznolikih psihomotoričnih sposobnosti (Molan in Molan, 2008).

\section{Ocenjevanje zaznavno-motoričnih sposobnosti}

V okviru merjenja sposobnosti spremljamo interakcijo z nalogo (odziv) in hitrost (odzivni čas). Osebe se med seboj razlikujejo glede na njihovo sposobnost ustreznega odziva in časa, ki ga za to porabijo. Razlike v ustreznosti odzivov in odzivnih časih so posledica medosebnih razlik $\mathrm{v}$ sposobnostih in hitrosti, kot tudi razlik $\mathrm{v}$ osebnostnih lastnostih (Goldhammer, 2015).

Mere za določitev potencialov kognitivnega procesiranja so hitrosti reakcijskih časov v odvisnosti od narave nalog oz. dražljajskih situacij. Merimo čas, ki ga posameznik potrebuje za informacijsko predelavo (Musek, 2005). Reakcijski čas je mera senzorne in motorične funkcije, ki vključuje zaznavo in predelavo dražljaja, čemur sledi sprožitev motoričnega odziva (Leonard, 1959).

Zaznavno-motorične sposobnosti preverjamo na aktivni, reaktivni in adaptivni ravni. Pri aktivnem predvajanju dražljajev se nov dražljaj predvaja po podanem ustreznem odgovoru. Pri reaktivnem predvajanju dražljajev je čas med predvajanimi dražljaji vnaprej določen. Pri adaptivnem načinu je hitrost predvajanja odvisna od hitrosti in natančnosti predhodnih odzivov (Schuhfried, 2017). Glavne komponente adaptivne preizkušnje obsegajo zbirko nalog/ dražljajev, proceduro na podlagi katere se izbirajo naloge/ dražljaji, metodo končnega izračuna rezultata po zaključku testiranja in pravila, ob katerih se preizkušnja ustavi (Green idr., 1984). Ena izmed ključnih lastnosti adaptivnega testiranja je določen proceduralni način predvajanja dražljajev. Sodobni informacijski sistemi omogočajo, da s programiranimi procedurami prilagajamo hitrost in zahtevnost dražljajev (Reckase, 1989). Tako po vnaprej določeni formuli predvajamo dražljaje s časovnimi omejitvami, ki se izračunavajo glede na hitrost in natančnost odzivov.

Oblika oz. procedura testa določa tudi prisotnost časovnega pritiska. Pospešena hitrost izvajanja (angl. Speededness) opisuje centralno značilnost preizkušenj in kaže stopnjo, na kateri je aktivnost pod vplivom časovnega pritiska (Goldhammer, 2015). Zadostna frekvenca predvajanih dražljajev v danem časovnem okviru vsakega posameznika postavi $\mathrm{v}$ situacijo, $\mathrm{v}$ kateri zahtevnost motoričnega odreagiranja doseže raven, ko oseba ni več zmožna ustreznega motoričnega odreagiranja (Kisser idr., 1986). Tako je določena raven psihomotoričnega funkcioniranja osebe v stresnem okolju in pod časovnim pritiskom (Schuhfried, 2017).

Po zahtevnosti se preizkušnje razlikujejo glede na to ali so merjeni enostavni ali izbirni reakcijski časi. Pri enostavnih reakcijskih časih sta motorični odziv in predvajana dražljajska situacija vedno enaka (Posner in McLeod, 1982). Pri izbirnih reakcijskih časih obstaja več možnosti motoričnih odgovorov. Predvajanje različnih dražljajskih situacij zahteva različne motorične odzive (Neubauer, 1990; Vernon, 1987).

Thurstone (1937) govori o verjetnosti ustreznega odgovora na dražljaj (nalogo) v odvisnosti od odzivnega časa in zahtevnosti dražljaja. Verjetnost pravilnega odgovora upada z zahtevnostjo naloge in se povečuje $\mathrm{z}$ daljšanjem odzivnih časov. Goldhammer (2015) opisuje obstoj notranjega razmerja med hitrostjo in natančnostjo pri posamezniku. Funkcije razmerja hitrost-natančnost kažejo, da posameznik v vsaki situaciji deluje na določeni ravni hitrosti in sposobnosti. Vedenje osebe je lahko v eni situaciji počasno in natančno, medtem ko bo v neki drugi situaciji hitro in nenatančno. Slog odzivanja lahko favorizira hitrost ali natančnost, odvisen pa je tudi od osebnostnih značilnosti testirane osebe. Popolno informacijo o razmerju med hitrostjo in natančnostjo posameznika dobimo, kadar se testiranje opravi v pogojih različnih časovnih obremenitev, s primerjavo povprečnih reakcijskih časov v določenih pogojih in z deležem napačnih odzivov (Gulliksen, 1950; Lohman, 1989).

Natančnost osebe ne more biti obravnavana kot samostojna mera, temveč kot padajoča funkcija, ki določa razmerje med natančnostjo in hitrostjo. Iz tega sledi, da individualne razlike $\mathrm{v}$ dosežkih na psihodiagnostičnih preizkušnjah določajo medosebne razlike $\mathrm{v}$ natančnosti in hitrosti (položaj posameznikove krivulje hitrost-natančnost) ter posameznikov notranji kompromis hitrost-natančnost (položaj znotraj posameznikove krivulje hitrost-natančnost; Goldhammer, 2015).

\section{Opredelitev problema}

V postopku ocenjevanja delazmožnosti je potrebno za oceno psihičnega funkcioniranja izbrati ustrezna psihodiagnostična sredstva, ki bodo dala ključne podatke o oceni zmožnosti posameznika za opravljanje dela in soočanje $\mathrm{z}$ obremenitvami $\mathrm{v}$ delovnem okolju. $\mathrm{V}$ prispevku je predstavljena uporaba psihodiagnostičnih instrumentov Vienna test system - VTS (Schuhfried, 2017) in Complex reactionmeter Drenovac - CRD (Drenovac, 1994) na vzorcu delovnih mest, za katere so po oceni tveganja značilne višje in visoke zahteve za zaznavno-motorični sistem. Vzorec obsega delovna mesta na področju varnostne in zdravstvene dejavnosti, dejavnosti prvih posredovalcev in različna delovna mesta $\mathrm{z}$ udeležbo $\mathrm{v}$ cestnem prometu.

Varnostno tveganje je v tem članku omejeno na zaznavnomotorično obremenitev $\mathrm{v}$ delovnem okolju, ki predstavlja večje tveganje za varnost in zdravje delavca ter drugih. Zanima nas, katere ocene, ki jih dobimo s pomočjo 
izvedenih zaznavno-motoričnih preizkušenj, v največji meri predstavljajo učinkovitost in slog psihomotoričnega funkcioniranja ter dajejo oceno zmožnosti posameznika za varno opravljanje dela $\mathrm{v}$ delovnih okoljih $\mathrm{z}$ večjim varnostnim tveganjem.

H1: Predvidevamo, da bodo odzivni časi krajši za preizkušnje enostavnejših zaznavno-motoričnih sposobnosti, ki ne zahtevajo razlikovanja dražljajev in orientacije v polju.

H2: Predvidevamo, da se bodo hitrosti motoričnih odzivov na preizkušnjah $\mathrm{z}$ aktivnim načinom prikazovanja dražljajev, pozitivno povezovale s hitrostjo motoričnih odzivov na preizkušnji, $\mathrm{z}$ adaptivnim načinom predvajanja dražljajev.

H3: Predvidevamo, da se bo hitrejša motorična odzivnost povezovala $z$ večjim številom napak, tako na preizkušnjah $\mathrm{z}$ adaptivnim kot $\mathrm{z}$ aktivnim predvajanjem dražljajev. Glede na višjo časovno obremenitev in nižjo kontrolo nad hitrostjo predvajanja dražljajev predvidevamo močnejšo povezanost na preizkušnji z adaptivnim draženjem.

H4: Predvidevamo, da se bo povečano število odzivov povezovalo s povečanim deležem napak in zmanjšano število odzivov s povečanim deležem izpustov.

\section{Metoda}

\section{Udeleženci}

V vzorec je bilo vključenih 198 udeležencev, od tega 128 (65 \%) moškega in 70 (35\%) ženskega spola. Vključeni so bili kandidati, ki že opravljajo dela ali kandidirajo za delovna mesta, na katerih so zaznavno-motorične zahteve ocenjene višje od povprečja. V vzorec so bila vključena različna delovna mesta $\mathrm{z}$ aktivnostmi, kot je vožnja motornih vozil, delo na višini, delo pod časovnimi pritiski, opravljanje zaznavno-motoričnih del ponoči in rokovanje s specialno delovno opremo. Vključena so bila delovna mesta s področja prvih posredovalcev, varnostne dejavnosti in redarstva ter diplomiranih zdravstvenih delavcev in zdravnikov. Povprečna starost udeležencev je bila 34 let $(S D=10,9)$.

\section{Pripomočki}

Preizkus enostavne orientacije v polju (CRD2) testnega sistema CRD ocenjuje sposobnost vidne orientacije $\mathrm{v}$ polju. Komandna plošča je sestavljena iz prečnih in navpičnih svetlobnih signalov $\mathrm{s}$ pomočjo katerih oseba določa položaj v polju na konzoli. Dobimo podatke o hitrosti in natančnosti enostavne orientacije $v$ polju. Naloga je sestavljena iz 35 različnih dražljajskih situacij. Posamezno dražljajsko situacijo sestavljata dva svetlobna signala, eden $\mathrm{v}$ navpični in eden $\mathrm{v}$ vodoravni liniji, in tako določata točko presečišča $\mathrm{v}$ polju konzole. Naloga preizkušanca je, kar se da hitro najti točko presečišča in pritisniti na tipko konzole, ki določa točko presečišča. V kolikor udeleženec ne poda ustreznega odgovora, konzola $\mathrm{z}$ glasovnim signalom opozori na neustreznost odgovora. Preizkušanec rešuje posamezno dražljajsko situacijo, dokler ne poda ustreznega odgovora. Preizkušnja se zaključi, ko udeleženec uspešno reši vseh 35 dražljajskih situacij. Merimo čas potreben za ustrezen odziv na posamezno dražljajsko situacijo $\mathrm{v}$ milisekundah, čas trajanja celotne preizkušnje v sekundah in število neustreznih rešitev (Drenovac, 1994).

Preizkušnji enostavne (CRD4a) in diferencialne (CRD4b) vidno motorične koordinacije testnega sistema CRD ocenjujeta sposobnost motoričnega reagiranja na dražljaje vidnega tipa, prilagajanja in izvajanja motorične aktivnosti $\mathrm{v}$ različnih kombinacijah uporabe vseh štirih ekstremitet telesa. Komandna plošča je sestavljena iz štirih lučk, vsaka izmed njih je namenjena posamezni ekstremiteti telesa. Dva gumba sta namenjena odzivom leve in desne roke, dva pedala sta namenjena odzivom leve in desne noge. Glede na predvajane dražljaje se preizkušana oseba na različne kombinacije predvajanih dražljajev odziva s pritiskanjem gumbov oz. stopalk. Na enojni dražljaj oseba odgovori s pritiskom ustreznega gumba ali stopalke. Ob predvajanju več dražljajev hkrati pa je zahtevan sočasen odziv, bodisi rok, nog ali kombinacija usklajenega odziva različnih ekstremitet. V preizkušnji CRD4a so predvajani enostavni dražljaji (vsi rdeče barve), v preizkušnji CRD4b pa izbirni dražljaji, ki zahtevajo razlikovanje med relevantnimi (zelenimi) in nerelavantnimi (rdečimi) dražljaji. Na preizkušnji CRD4b dražljaji rdeče barve delujejo kot motilci, ki jih preizkušani ne sme upoštevati in se mora odzivati zgolj na dražljaje zelene barve. Preizkušnji sta sestavljeni iz 35 dražljajskih situacij. $\mathrm{V}$ kolikor udeleženec ne poda ustreznega odgovora, konzola z glasovnim signalom opozori na neustreznost odgovora. Preizkušanec rešuje posamezno dražljajsko situacijo, dokler ne poda ustreznega odgovora. Preizkušnja se zaključi, ko udeleženec uspešno reši vseh 35 dražljajskih situacij. Merimo čas rešitve posamezne dražljajske situacije $\mathrm{v}$ milisekundah, čas trajanja celotne preizkušnje v sekundah in število neustreznih rešitev (Drenovac, 1994).

Preizkus razpršene pozornosti in motoričnega odzivanja (DT-S1) testnega sistema VTS je psihodiagnostični inštrument, sestavljen iz računalniškega programa in pripomočkov namenjenih testiranju. Oseba naloge, ki se predvajajo na zaslonu računalnika, rešuje $\mathrm{z}$ motoričnimi odzivi na gumbe glavne konzole ter na dva nožna pedala. Preizkus razpršene pozornosti in motoričnega odzivanja je preizkušnja odpornosti na stres, pozornosti in reaktivne hitrosti $\mathrm{v}$ situaciji, ki zahteva kontinuirano odzivanje in prilagajanje na spremembe vidnih in slušnih dražljajev. Rezultati kažejo aktivnost v stresnih okoljih, sposobnost prilagajanja, odzivanja in vzdrževanja kontinuitete odzivov ter hitrost in natančnost motorične odzivnosti. Preizkušnja aktivira psihične funkcije, ki omogočajo izbiro med različnimi vrstami dražljajev ter izbiro in izvedbo motoričnega odziva, glede na vrsto predvajanega dražljaja in zahtevano hitrost reakcije. Preizkušnja je v celoti računalniško vodena. $\mathrm{V}$ začetku se oseba najprej seznani $\mathrm{z}$ nalogo in naredi računalniško vodeno vajo, ki ji sledi štiri minutna testna preizkušnja. Celotna izvedba preizkušnje traja približno 8 minut. Naloga je sestavljena iz zaporedja vidnih in slušnih dražljajev. Dražljaje vidnega tipa predstavljajo signali različnih barv (bela, rumena, rdeča, zelena, modra), ki zahtevajo motorični odziv rok ter dva vidna dražljaja, ki zahtevata odziv leve oz. desne noge. Prisotna sta tudi različna 


\section{Tabela 1}

Opisna statistika za vse merjene spremenljivke preizkušenj DT-S1, CRD2, CRD4a in CRD4b

\begin{tabular}{|c|c|c|c|c|c|c|c|c|}
\hline & $M$ & $M d n$ & $M o$ & $S D$ & $\min$ & $\max$ & $K S$ & $p$ \\
\hline DT-S1 pravilni & 248,14 & 248,00 & 242,00 & 33,31 & 158,00 & 330,00 & 0,44 & 0,990 \\
\hline DT-S1 napake & 19,74 & 17,00 & 14,00 & 11,71 & 1,00 & 69,00 & 2,01 & 0,001 \\
\hline DT-S1 izpusti & 13,20 & 13,00 & 9,00 & 6,64 & 2,00 & 35,00 & 1,55 & 0,016 \\
\hline DT-S1 RT (sek.) & 0,77 & 0,75 & 0,75 & 0,09 & 0,59 & 1,2 & 1,74 & 0,005 \\
\hline DT-S1 vsi dražljaji & 268,55 & 270,00 & 282,00 & 32,03 & 172,00 & 343,00 & 0,71 & 0,695 \\
\hline DT-S1 vsi odzivi & 267,87 & 271,00 & 284,00 & 35,81 & 169,00 & 352,00 & 0,69 & 0,725 \\
\hline CRD2 skupen čas & 44,91 & 42,79 & 42,60 & 9,22 & 28,52 & 86,96 & 1,46 & 0,029 \\
\hline CRD2 napake & 0,70 & 0,00 & 0,00 & 1,22 & 0,00 & 9,00 & 4,61 & $<0,001$ \\
\hline CRD2 RT (sek.) & 1,26 & 1,22 & 1,22 & 0,24 & 0,81 & 2,35 & 1,41 & 0,037 \\
\hline CRD4a skupen čas & 35,00 & 33,37 & 30,25 & 11,57 & 17,52 & 84,78 & 1,56 & 0,015 \\
\hline CRD4a napake & 4,44 & 3,00 & 1,00 & 4,56 & 0,00 & 32,00 & 2,32 & $<0,001$ \\
\hline CRD4a RT (sek.) & 0,88 & 0,85 & 0,74 & 0,24 & 0,47 & 1,84 & 1,31 & 0,065 \\
\hline CRD4b skupen čas & 44,63 & 42,22 & 35,93 & 13,45 & 21,93 & 85,81 & 1,25 & 0,087 \\
\hline CRD4b napake & 5,50 & 4,00 & 4,00 & 4,88 & 0,00 & 41,00 & 2,42 & $<0,001$ \\
\hline CRD4b RT (sek.) & 1,10 & 1,05 & 0,59 & 0,29 & 0,59 & 2,15 & 1,10 & 0,181 \\
\hline
\end{tabular}

Opombe: DT-S1 - Preizkus razpršene pozornosti in motoričnega odzivanja, CRD2 - Preizkus enostavne orientacije v polju, CRD4a Preizkus enostavne vidno motorične koordinacije, CRD4b - Preizkus diferencialne vidno motorične koordinacije, $K S$ - Kolmogrov Smirnov test normalnosti.

zvočna signala (visok in nizek ton), na katera se oseba odzove s pritiskom na tipko za visok oz. nizek ton. Dražljaji so predvajani v adaptivnem načinu tako, da se hitrost predvajanja prilagaja glede na natančnost in odzivnost preizkušanca. Hitrejši in natančnejši odzivi pomenijo manj časa za odziv na naslednji predvajani dražljaj. Preizkušnja meri hitrost motoričnih odreagiranj v sekundah, število vseh ustreznih, napačnih in izpuščenih odzivov ter število vseh predvajanih dražljajev in vseh odzivov (Schuhfried, 2017).

\section{Postopek}

Udeleženci so bili obravnavani v okviru zdravniškega pregleda za oceno delazmožnosti na Kliničnem inštitutu za medicino dela, prometa in športa - Univerzitetni klinični center Ljubljana. Izvedba preizkušenj je potekala $\mathrm{v}$ dopoldanskem času. Izvedena je bila individualno v testirni sobi, kjer se je udeležencem omogočilo izvajanje brez motečih dejavnikov. V prvem koraku je bil vsak udeleženec seznanjen

\section{Tabela 2}

Spearmanovi korelacijski koeficienti med odzivnimi časi na preizkušnjah DT-S1, CRD2, CRD4a in CRD4b

\begin{tabular}{lccc}
\hline & CRD 2 & CRD 4a & CRD 4b \\
\hline DT-S1 &, $62^{* *}$ &, $49^{* *}$ &, $54^{* *}$ \\
CRD 2 & &, $58^{* *}$ &, $60^{* *}$ \\
CRD 4a & & &, $85^{* *}$ \\
\hline
\end{tabular}

${ }^{* *} p<0,01$ s potekom preizkušenj in kratko predstavitvijo preizkušenj. Postopek preizkušenj je bil za vse udeležence enak. Najprej je bila izvedena preizkušnja CRD2, ki ji je sledila izvedba preizkušnje CRD4a in CRD4b. Nazadnje so udeleženci izvedli še preizkušnjo DT-S1. Pred preizkušnjami CRD je testator najprej natančno predstavil navodila posamezne preizkušnje. Nato je udeleženec naredili set nalog za vajo, katerim je sledila še izvedba preizkušnje. S posamezno preizkušnjo CRD je udeleženec zaključil, ko je uspešno rešil vseh 35 dražljajskih situacij. Preizkušnja DT-S1 je bila v celoti računalniško vodena, testator je podal zgolj uvodno usmeritev v nalogo. Udeleženci so sledili navodilom na zaslonu računalnika tako, da so se najprej spoznali z vsemi komponentami konzole (gumbi, stopalki) in izvedli preizkušnje za vajo. Po opravljenih preizkušnjah za vajo je računalnik podal navodila za izvedbo preizkušnje, ki je bila časovno omejena na štiri minute. Ob zaključku so bili udeležencem predstavljeni njihovi dosežki na preizkušnjah.

\section{Tabela 3}

Spearmanovi korelacijski koeficienti med spremenljivkami preizkušnje razpršene pozornosti in motoričega odzivanja (DT-S1)

\begin{tabular}{lccc}
\hline & DT-S1 napake & DT-S1 izpusti & DT-S1 RT (sek.) \\
\hline DT-S1 pravilni &, 03 &,$- 39^{* *}$ &,$- 81^{* *}$ \\
DT-S1 napake & &, $24^{* *}$ &,$- 32^{* *}$ \\
DT-S1 izpusti & & &,- 09 \\
\hline
\end{tabular}




\section{Rezultati}

Primerjava časov motoričnih odzivov kaže, da so bili v povprečju doseženi najkrajši časi odzivov na preizkušnji DT-S1 in CRD4a. Na preizkušnji CRD2 in CRD4b so bili časi daljši in znašajo več kot eno sekundo (tabela 1). Najvišja povezanost časov motoričnih odzivov je med preizkušnjama CRD4a in CRD4b. Povezanost odzivnih časov se kaže tudi glede na način predvajanja dražljajev. Odzivni časi na preizkušnji z adaptivnim draženjem (DT-S1) se statistično pomembno povezujejo s časi vseh preizkušenj z aktivnim draženjem (preizkušnje CRD) (tabela 2).

Osebe s krajšimi odzivnimi časi so na časovno omejeni preizkušnji DT-S1 podale statistično pomembno večje število pravilnih odzivov, prav tako so osebe s krajšimi odzivnimi časi hitreje zaključile z izvedbo preizkušenj CRD. Natančnost odzivov na preizkušnjah kaže obratno povezanost med preizkušnjami CRD in preizkušnjo DT-S1. Krajši odzivni časi na preizkušnjah CRD se povezujejo z manjšim številom napak. Na preizkušnji DT-S1 se krajši odzivni časi povezujejo s povečanim številom napak (tabeli 3 in 4). Spremenljivka števila izpuščenih dražljajev, ki jo merimo samo na preizkušnji DT-S1, ne kaže povezanosti z odzivnimi časi, pomembno pa je povezana s številom pravilnih odzivov (tabela 3). Za ugotavljanje vpliva razmerja hitrost-natančnost smo uporabili celoten vzorec vključenih oseb in analizirali podatke preizkušnje DT-S1. Rezultati kažejo, da so se v povprečju udeleženci na 7,3 \% dražljajev odzvali napačno $(S D=4,02)$ in se niso odzvali na 5,1\% predvajanih dražljajev $(S D=2,80)$. Kot je razvidno iz tabele 1 , je povprečen odzivni čas na preizkušnji DT-S1 znašal 0,77 sekunde. Število pravilnih odzivov predstavlja glavno spremenljivko preizkušnje DT-S1 in se negativno povezuje s številom izpuščenih dražljajev, medtem ko se s številom napačnih odzivov ne povezuje (tabela 3).

Ustvarili smo novo spremenljivko tako, da smo izračunali razliko med številom vseh predvajanih dražljajev in številom vseh odzivov, ki jih je oseba naredila: $n$ (predvajanih dražljajev) - $n$ (odzivov). Osebam, pri katerih je bilo število odzivov enako številu predvajanih dražljajev, je $\mathrm{v}$ novi spremenljivki dodeljena vrednost nič $(n=0)$. Osebe, ki so naredile več odzivov kot je bilo predvajanih dražljajev, imajo negativno vrednost $(n<0)$. Obratno, pozitivno vrednost $(n>0)$ imajo osebe, ki so naredile manj odzivov, kot je bilo predvajanih dražljajev. Povprečna vrednost novo izračune spremenljivke (razlika med številom vseh predvajanih dražljajev in številom vseh odzivov) je znašala 0,67 in se normalno porazdeljuje $\left(X_{\mathrm{Min}}=-32 ; X_{\mathrm{Max}}=25 ; M d n=1\right.$; $S D=10,42 ; Q R=14 ; K S=0,85 ; p=0,465)$. Podatki kažejo, da med odzivnimi časi in novo izračunano spremenljivko ni močnejše povezave $(r=0,14 ; p=0,04)$. Število pravilnih odzivov je statistično pomembno povezano $\mathrm{z}$ deležem izpustov $(r=-0,56 ; p<0,001)$. Povezanost $\mathrm{z}$ deležem napak je manjša $(r=-0,17 ; p=0,014)$. Število pravilnih odzivov kaže večjo povezanost $\mathrm{z}$ deleži napak in izpustov (tabela 5) kot s številom napak in izpustov (tabela 3).

$\mathrm{Z}$ upoštevanjem teoretične vrednosti nove izračunane spremenljivke $(» n \ll)$, ki v primeru odsotnosti neustreznega in izpuščenega odziva znaša nič $(n=0)$ in ob upoštevanju standardnega odklona vzorca $(S D=10,42)$, smo udeležence razdelili v tri skupine:

- skupina 1: osebe, $\mathrm{z}$ vrednostjo nove spremenljivke med -5 in $5(-5 \geq n \leq 5)$,

- skupina 2: osebe, $\mathrm{z}$ vrednostjo nove spremenljivke večje od $5(n>5)$,

- skupina 3: osebe, $\mathrm{z}$ vrednostjo nove spremenljivke manjše od $-5(n<-5)$.

Deskriptivna statistika preizkušnje DT-S1 po skupinah glede na novo spremenljivko je prikazana $\mathrm{v}$ prilogi (tabela P1). V povprečju je največje število ustreznih odzivov, V časovno omejeni preizkušnji, naredila skupina 3 . V primerjavi s preostalima skupinama pa je $\mathrm{v}$ tem časovnem intervalu preizkušnje, imela tudi bistveno večji delež napak. Najmanjše število pravilnih odzivov je naredila skupina 2, ki ima glede na preostali skupini večji delež izpustov. Skupina 1 je na ravni deleža napak primerljiva s skupino 2 in na ravni deleža izpustov s skupino 3. Razporeditve odstotkov napak in izpustov po skupinah so prikazane na slikah 1 in 2. Rezultate skupin smo preverili s Kruskal-Wallis testom. Rezultati kažejo, da se med skupinami vrednosti vseh merjenih spremenljivk preizkušnje DT-S1 statistično pomembno razlikujejo, mejna vrednost je razvidna le za spremenljivko odzivnih časov (tabela 6). Podrobnejša primerjava skupin z Dunn-Bonferroni post-hoc testom kaže statistično pomembno odstopanje, za spremenljivko »število pravilnih odzivov« skupine 1 in skupine $2(p=0,009)$ ter skupine 2 in skupine $3(p<0,001)$. Za spremenljivki »število napak«

\section{Tabela 4}

Spearmanovi korelacijski koeficienti med spremenljivkami preizkušenj CRD

\begin{tabular}{|c|c|c|c|c|c|c|c|c|}
\hline & CRD 2 napake & CRD 2 RT & CRD 4a čas & CRD 4a napake & CRD 4a RT & CRD 4b čas & CRD 4b napake & CRD 4b RT \\
\hline CRD 2 čas &, $35^{* *}$ & ,99** &, $63^{* *}$ & $31^{* *}$ &, $59^{* *}$ &, $63^{* *}$ & $23^{* *}$ &, $60^{* *}$ \\
\hline CRD 2 napake & &, $22^{* *}$ &, $19^{* *}$ & ,12 &, $18^{*}$ &, $20^{* *}$ & ,09 &, $17^{*}$ \\
\hline CRD 2 RT & & &, $62^{* *}$ &, $30^{* *}$ &, $58^{* *}$ &, $62^{* *}$ & $23^{* *}$ &, $60^{* *}$ \\
\hline CRD 4a čas & & & &, $45^{* *}$ &, $93^{* *}$ &, $83^{* *}$ & $25^{* *}$ &, $84^{* *}$ \\
\hline CRD 4a napake & & & & &, $16^{*}$ &, $41^{* *}$ &, $49^{* *}$ &, $26^{* *}$ \\
\hline CRD 4a RT & & & & & &, $76^{* *}$ & ,08 &, $85^{* *}$ \\
\hline CRD $4 b$ čas & & & & & & &, $47^{* *}$ &, $92^{* *}$ \\
\hline CRD 4b napake & & & & & & & & $15^{*}$ \\
\hline
\end{tabular}

Opombe: CRD2 - Preizkus enostavne orientacije v polju, CRD4a - Preizkus enostavne vidno motorične koordinacije, CRD4b - Preizkus diferencialne vidno motorične koordinacije, ${ }^{* *} p<0,01,{ }^{*} p<0,05$. 


\section{Tabela 5}

Spearmanovi korelacijski koeficienti za št. pravilnih odzivov, deleže napak in izpustov ter novo izračunano spremenljivko razlike med številom predvajanih dražljajev in odzivov, na preizkušnji razpršene pozornosti in motoričnega odzivanja (DTS1)

\begin{tabular}{lcccc}
\hline & DT-S1 RT & \% napak & \% izpuščenih & $\begin{array}{c}\mathrm{n} \\
\text { (št. dražljajev }- \text { št. odzivov) }\end{array}$ \\
\hline DT-S1 pravilni &,$- 81^{* *}$ &,$- 17^{*}$ &,$- 56^{* *}$ &,$- 32^{* *}$ \\
DT-S1 RT & &,$- 14^{*}$ &, 11 &, $14^{*}$ \\
\% napak & & &, $25^{* *}$ &,$- 47^{* *}$ \\
\% izpuščenih & & & &, $62^{* *}$ \\
\hline
\end{tabular}

Opombe: ${ }^{* *} p<0,01,{ }^{*} p<0,05$.

in »odstotek napak« je razvidno statistično pomembno odstopanje med skupino 1 in skupino $3(p<0,001)$ ter skupino 2 in skupino $3(p<0,001)$. Za spremenljivki »število izpustov« in »odstotek izpustov« je razvidno statistično pomembno odstopanje med skupino 1 in skupino 2 $(p<0,001)$ ter skupino 2 in skupino $3(p<0,001)$. Spremenljivka »hitrost odzivnih časov« glede na rezultate post-hoc testa ne kaže statistično pomembnih odstopanj med skupinami. Za oceno mere učinka smo uporabili koeficient Pearsonove korelacije (tabela 6).

Podatke, ločeno na skupine, smo preverili še za preizkušnje z aktivnim tipom predvajanja dražljajev na preizkušnjah CRD. Deskriptivni podatki so prikazani v tabeli P1. Skupina 3 je preizkušnje CRD opravila najhitreje, imela je najkrajše odzivne čase, pri tem pa je bila najmanj natančna. Največjo natančnost odzivov je na vseh preizkušnjah CRD dosegla skupina 2, ki pa je bila po hitrosti odzivov tudi najpočasnejša. Kruskal-Wallis test kaže statistično pomembno odstopanje med skupinami za spremenljivko »število napak» na preizkušnji CRD2, spremenljivki hitrosti odzivnih časov na preizkušnjah CRD4a, CRD4b in celotnim časom, ki so

\section{Slika 1}

Prikaz deležev napak glede na skupine ločene po spremenljivki razlike med številom dražljajev in odzivov, na preizkušnji razpršene pozornosti in motoričnega odzivanja (DT-S1)

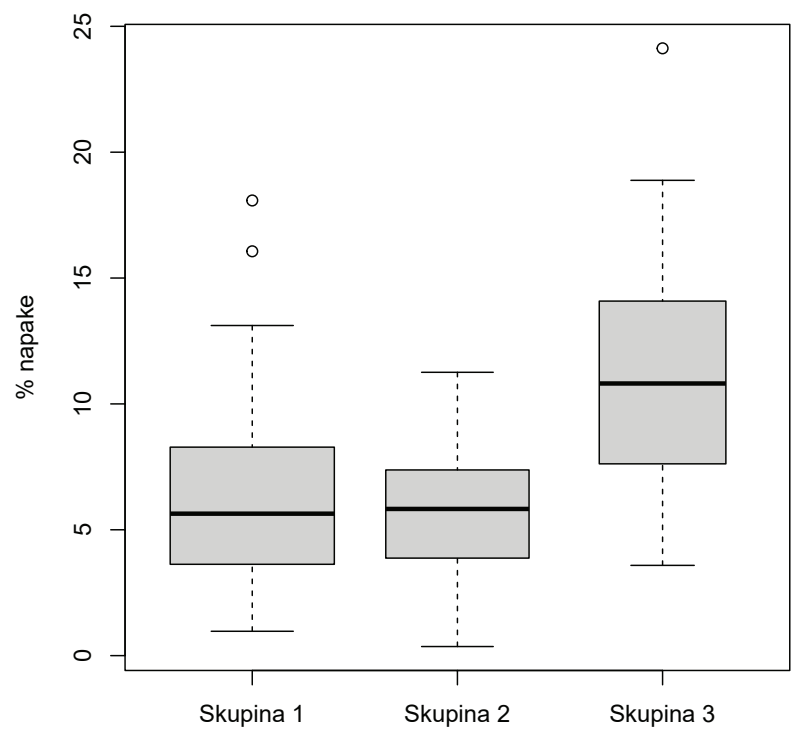

ga osebe porabile za izvedbo preizkušnje CRD4a (tabela 6). Podrobnejša primerjava skupin v parih z Dunn-Bonferroni testom kaže na statistično pomembna odstopanja med skupino 2 in skupino 3 za spremenljivki »čas potreben za izvedbo preizkušnje« CRD4a $(p=0,036)$ in »hitrost odzivnih časov« na preizkušnji CRD4b $(p=0,021)$. Za preostale spremenljivke post-hoc analiza skupin primerjanja $\mathrm{v}$ parih ni pokazala statistično pomembnih odstopanj.

\section{Razprava}

Ugotavljanje zaznavno-motorične sposobnosti je pomembno za ocenjevanje zmožnosti za delo $\mathrm{v}$ delovnih okoljih s povečanimi varnostnimi tveganji. V raziskavi nas je zanimalo, kateri so glavni pokazatelji zaznavno-motoričnih sposobnosti, ki jih dobimo s pomočjo preizkušenj CRD2, CRD4a, CRD4b in DT-S1 ter kako jih lahko interpretiramo v ocenjevanju zmožnosti za delo. Podrobneje smo analizirali spremenljivki hitrosti in natančnosti motoričnih odzivov in obravnavali vpliv aktivnega in adaptivnega načina predvajanja dražljajev v testnih preizkušnjah.

\section{Slika 2}

Prikaz deležev izpustov glede na skupine ločene po spremenljivki razlike med številom dražljajev in odzivov, na preizkušnji razpršene pozornosti in motoričnega odzivanja (DT-SI)

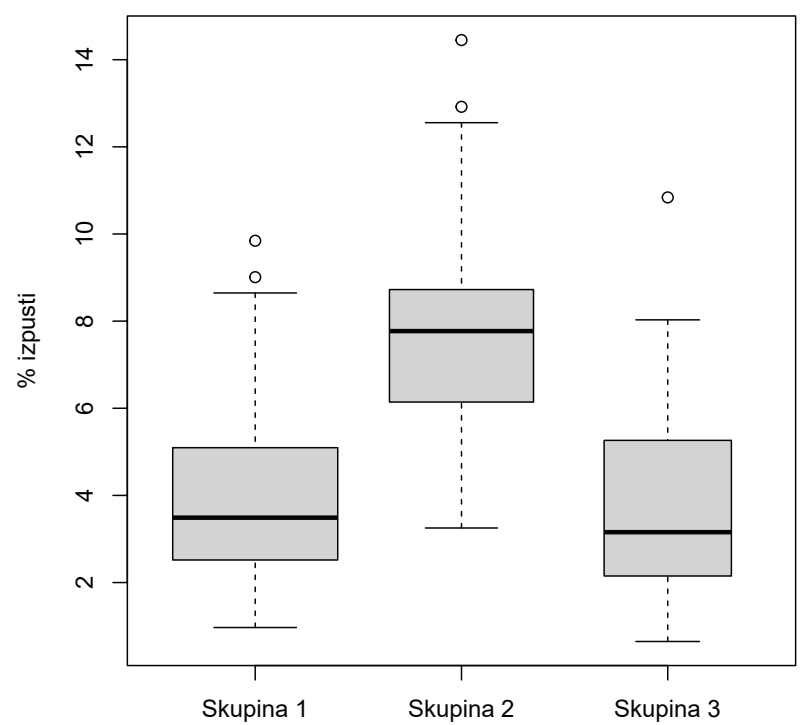


Tabela 6

Kruskal Wallisov test primerjave skupin za spremenljivke preizkušnje DT-S1, CRD2 in CRD4 in ocena mere učinka s koeficientom Pearsonove korelacije

\begin{tabular}{|c|c|c|c|c|c|c|}
\hline & $\chi^{2}$ & $d f$ & $p$ & $\begin{array}{c}r \\
\text { (skupina 1-2) }\end{array}$ & $\begin{array}{c}r \\
\text { (skupina 1-3) } \\
\end{array}$ & $\begin{array}{c}r \\
\text { (skupina 2-3) } \\
\end{array}$ \\
\hline DT-S1 pravilni & 16,967 & 2 & $<0,001$ & 0,37 & $-0,29$ & $-0,48$ \\
\hline DT-S1 napake & 66,242 & 2 & $<0,001$ & 0,21 & $-0,60$ & $-0,66$ \\
\hline DT-S1 izpuščeni & 70,85 & 2 & $<0,001$ & $-0,62$ & $-0,11$ & 0,60 \\
\hline DT-S1 RT (sek.) & 6,005 & 2 & 0,050 & 0,10 & 0,33 & 0,31 \\
\hline DT-S1 \% napake & 50,934 & 2 & $<0,001$ & 0,13 & $-0,57$ & $-0,61$ \\
\hline DS-S1 \% izpuščeni & 80,505 & 2 & $<0,001$ & $-0,63$ & 0,17 & 0,65 \\
\hline CRD 2 čas & 2,897 & 2 & 0,235 & $-0,22$ & 0,21 & 0,29 \\
\hline CRD 2 napake & 6,322 & 2 & 0,042 & 0,09 & $-0,33$ & $-0,34$ \\
\hline CRD 2 RT (sek.) & 4,553 & 2 & 0,103 & $-0,23$ & 0,25 & 0,25 \\
\hline CRD 4a čas & 6,554 & 2 & 0,038 & $-0,30$ & 0,21 & 0,36 \\
\hline CRD 4a napake & 1,89 & 2 & 0,389 & 0,15 & 0,30 & 0,17 \\
\hline CRD 4a RT (sek.) & 6,352 & 2 & 0,042 & $-0,32$ & 0,16 & 0,35 \\
\hline CRD 4b čas & 4,184 & 2 & 0,123 & $-0,21$ & 0,25 & 0,32 \\
\hline CRD 4b napake & 1,857 & 2 & 0,395 & 0,23 & 0,07 & $-0,26$ \\
\hline CRD 4b RT (sek.) & 7,32 & 2 & 0,026 & $-0,26$ & 0,28 & 0,37 \\
\hline
\end{tabular}

Opombe: DT-S1 - Preizkus razpršene pozornosti in motoričnega odzivanja, CRD2 - Preizkus enostavne orientacije v polju, CRD4a - Preizkus enostavne vidno motorične koordinacije, CRD4b - Preizkus diferencialne vidno motorične koordinacije.

\section{Hitrosti motoričnih odreagiranj se povezujejo z zahtevnostjo nalog}

Tudi rezultati naše raziskave kažejo povezanost odzivnih časov in zahtevnosti preizkušenj (Neubauer, 1990; Posner in McLeod, 1982; Vernon, 1987). Na vseh preizkušnjah CRD in DT-S1 ugotavljamo povezanost odzivnih časov $\mathrm{z}$ zahtevnostjo med posameznimi preizkušnjami. Daljši odzivni časi na preizkušnji CRD2 in CRD4b kažejo na kognitivno zahtevnejšo obdelavo podatkov, ki vključuje orientacijo v polju in razlikovanje dražljajev. Na preizkušnjah DT-S1 in CRD4a, kjer je zahtevana kognitivna obdelava na ravni prepoznave dražljajev in enostavnejših motoričnih odreagiranj, so odzivni časi krajši. Rezultati potrjujejo prvo hipotezo, v kateri smo predvidevali krajše odzivne čase na preizkušnjah enostavnejših zaznavno-motoričnih sposobnosti, ki ne zahtevajo razlikovanja dražljajev in orientacije v polju.

\section{Natančnost odzivov se povezuje s komponento časovne obremenitve in je odvisna od zahtevnosti dražljajske situacije}

Odzivni časi med preizkušnjami se pozitivno povezujejo ne glede na način predvajanja dražljajev in potrjujejo hipotezo o povezanosti odzivnih časov med preizkušnjami. Ugotovitve potrjujejo predpostavko, da hitrosti reakcijskih časov lahko služijo kot temeljna mera pri določanju potencialov kognitivnega procesiranja (Musek, 2005).

Ugotavljamo, da so udeleženci dosegali najkrajše odzivne čase na preizkušnji z adaptivnim načinom prikazovanja. Krajši odzivni časi so se na preizkušnji z adaptivnim draženjem povezovali $\mathrm{z}$ večjim številom napak, na preizkušnjah $\mathrm{z}$ aktivnim predvajanjem dražljajev pa $\mathrm{z}$ manjšim številom napak. Tretjo hipotezo lahko potrdimo v delu, ki se nanaša na adaptivni tip predvajanja dražljajev. Nasprotno od pričakovanega so se krajši odzivni časi na preizkušnjah orientacije $\mathrm{v}$ polju in vidno motorične koordinacije namreč povezovali z manjšim številom napak. Glede na rezultate lahko sklepamo, da je natančnost motoričnih odreagiranj odvisna tako od časovne obremenitve, kot od vsebine oz. zahtevnosti zaznavno-motorične naloge. Pri natančnosti odzivov se je pokazala pomembnost komponente časovne obremenitve in nižjega nadzora nad nalogo, ki vpliva na večjo verjetnost napačnega motoričnega odreagiranja.

\section{Učinkovitost motoričnih odreagiranj je odvisna od razmerja med hitrostjo in natančnostjo}

Rezultati analize potrjujejo, da je poleg same hitrosti in natančnosti motoričnega odzivanja potrebno upoštevati tudi razmerje med obema spremenljivkama, ti. razmerje hitrostnatančnost (Goldhammer, 2015). Rezultati analize generirane spremenljivke »n« kažejo, da je upoštevanje razlike med številom predvajanih dražljajev in številom odzivov pomembno povezano s testnimi dosežki oseb na preizkušnji DT-S1. Interpretacija testnega dosežka mora poleg števila napak in izpustov vključevati tudi delež napak in izpustov, ki jih oseba naredi glede na obremenitev, ki ji je izpostavljena (število predvajanih dražljajev v časovnem okvirju). Ob tem se je spremenljivka »n« pokazala kot pomemben pokazatelj tudi na ravni odstopanj v značilnostih motoričnih odreagiranj skupin udeležencev. 
Adaptivni način predvajanja dražljajev na preizkušnji DT-S1 daje možnost, da slog odzivanja osebe tudi nominalno ovrednotimo. Rezultati potrjujejo hipotezo o povezanosti deleža napak in izpustov $\mathrm{z}$ odzivnostjo osebe. Povečana odzivnost se kaže skozi povečan delež napak in znižana odzivnost skozi povečan delež izpustov. Interpretacija podatkov izključno na podatku o številu pravilnih, napačnih in izpuščenih odzivov, je lahko nepopolna. Vzorec udeležencev smo glede na raven odzivnosti razdelili $\mathrm{v}$ tri skupine. Pri skupini 3 s povišano odzivnostjo ugotavljamo povečan delež napak ter pri skupini 2 povečan delež izpustov. V skupini 3 se kaže impulzivnejši slog odzivanja, ki favorizira hitrost odziva. Pri skupini 2 je v ospredju natančnost in previdnejši slog motoričnega odreagiranja. Skupina 1, v katero so bile vključene osebe s primerljivim številom dražljajev in odzivov, kaže uravnoteženost merjenih spremenljivk hitrosti, natančnosti in sposobnosti ohranjanja odzivov pod časovnim obremenjevanjem. V primerjavi s preostalima skupinama se kaže kot učinkovitejša pri izvajanju zaznavno-motoričnih aktivnosti pod časovnim pritiskom. Temeljna spremenljivka preizkušnje DT-S1 (število pravilnih odzivov), se pomembno povezuje $\mathrm{z}$ deležem izpustov in slogom odzivanja, ki ga dobimo iz razlike med predvajanimi dražljaji in odzivi. Ugotovitve o značilnostih motoričnih odreagiranj posamezne skupine se skladajo tudi z opisi značilnosti odzivnih stilov kot jih opisuje Goldhammer (2015). Odzivni stil osebe favorizira bodisi hitrost ali natančnost motoričnega odreagiranja.

Varnostno tvegane situacije predstavljajo delovna mesta, kjer je otežena kontrola nad delom, prisoten vsiljen ritem dela in nepredvidljivost dogodka, ki zahteva takojšnje ukrepanje. Glede na rezultate preizkušnje $\mathrm{z}$ adaptivnim draženjem ugotavljamo, da za zagotavljanje varnega opravljanja dela v takšnih okoljih sama hitrost in natančnost odzivov ne zadošča. Pomembna je ustrezna uravnoteženost psihomotoričnega funkcioniranja, ki jo določa tudi razmerje med hitrostjo in natančnostjo ter sposobnost ohranjanja učinkovitosti motoričnih odzivov. Nezmožnost sledenja senzorni obremenitvi se kaže skozi odsotnost reagiranja in neustrezne motorične odzive. Na drugi strani pa preizkušnje z aktivnim draženjem kažejo, da je tveganje za napake nižje pri opravljanju del v predvidljivem okolju, na diskretnih motoričnih opravilih, $\mathrm{z}$ dobro kontrolo nad delom in brez pristnosti vsiljenega ritma. $\mathrm{V}$ takšnih okoljih se bodo osebe s hitrejšo odzivnostjo izkazale kot učinkovitejše, delo bodo opravile hitreje in bolj natančno.

\section{Omejitve raziskave in predlogi za nadaljnje delo}

$\mathrm{V}$ analizi so bile uporabljene povprečne vrednosti odzivnih časov na posamezni preizkušnji. Znotraj posameznih preizkušenj so zahtevnosti dražljajskih situacij različne. Zahtevnost posameznih koordiniranih odzivanj se med seboj razlikuje, ker je potrebno razlikovanje različnih modalitet dražljajev. V opravljeni analizi nismo upoštevali variacij zahtevnosti dražljajskih situacij znotraj posameznih preizkušenj. Analiza, opravljena na ravni preučevanja odzivnih časov glede na zahtevnost posamezne dražljajske situacije, bi podala natančnejši vpogled v medosebne razlike v sposobnosti in hitrosti. Preučevanje posameznih odzivov bi bilo potrebno tudi $\mathrm{z}$ vidika določanja individualne učinkovitosti posameznika, ki vpliva na testno uspešnost (Goldhammer, 2015).

Vzorec udeležencev je selektiven, izbran na podlagi formalne stopnje izobrazbe in dodatnih specialnih znanj ter izkušenj, ki se za opravljanje dela $\mathrm{v}$ okoljih $\mathrm{z}$ večjim varnostnim tveganjem zahtevajo. Pri obravnavi posameznih elementov zaznavno-motoričnih sposobnosti in stilov odzivanja bi bilo potrebno upoštevati tudi demografske dejavnike vpliva (starost, spol, izobrazba, delovne izkušnje), ki lahko pomembno vplivajo na merjene spremenljivke preizkušenj. V vzorec vključeni udeleženci so lahko, zaradi namena pregleda $\mathrm{v}$ okviru katerega so bili obravnavani, doživljali tudi dodaten stres, ki bi lahko bil v drugačni testni situaciji manj izrazit. Zaradi vpliva posameznikove strategije reševanja, odzivnega sloga in pomembnosti same preizkušnje, bi se to lahko kazalo $\mathrm{v}$ različni individualni učinkovitosti informacijskega procesiranja. Podatke bi bilo smiselno preveriti še na splošni populaciji in preveriti povezanost $\mathrm{z}$ demografskimi in testnimi dejavniki.

\section{Zaključek}

Pri opravljanju dela $z$ večjim tveganjem za poškodbe in nesreče lahko delavec $\mathrm{z}$ neprilagojenim vedenjem ogrozi svojo varnost, varnost drugih ali okolja. Za zagotavljanje učinkovitega vedenja $\mathrm{v}$ varnostno zahtevnih situacijah so potrebne ustrezne psihomotorične sposobnosti delavca. Vsebino psihološkega pregleda za oceno delazmožnosti določa ocena tveganj. V oceni tveganja so opredeljene zahteve na podlagi katerih določamo aplikacijo psihodiagnostičnih sredstev za oceno splošnih in specialnih sposobnosti.

Zmožnosti motoričnega odreagiranja se kažejo v izvedbi motorične aktivnosti glede na dražljajsko situacijo in okolje. Opravljena analiza podatkov dobljenih s pomočjo psihodiagnostičnih inštrumentov DT-S1, CRD2 in CRD4a in CRD4b kaže na pomembne značilnosti motoričnega reagiranja, ki jih je potrebno pri ocenjevanju delazmožnosti upoštevati. Rezultati kažejo, da je pri oceni psihomotoričnih zmožnosti pomembno upoštevati hitrost odzivnih časov, razmerje med hitrostjo in natančnostjo motoričnih odreagiranj in sposobnost ohranjanja motorične odzivnosti pod časovnimi obremenitvami. Ugotavljamo, da je pri izbiri psihodiagnostičnih sredstev pomemben tudi način predvajanja dražljajev v preizkušnji. Preizkušnja DT-S1, v katerih je način predvajanja dražljajev adaptiven in zahteva kontinuirano motorično aktivnost, daje širšo oceno psihomotoričnih sposobnosti in omogoča oceno ključnih elementov zaznavno-motoričnih sposobnosti.

Za potrebe ugotavljanja zmožnosti opravljanja dela $\mathrm{v}$ varnostno tveganih okoljih se uporaba adaptivnega testiranja, ki zahteva obdelavo različnih modalnosti dražljajev, kaže kot primernejša. Aktivni način predvajanja dražljajev je primernejši za prevajanje zmožnosti za opravljanje motorično manj zahtevnih, diskretnih delovnih opravil ali za oceno specifičnih sposobnosti značilnih za določeno delovno opravilo. 


\section{Literatura}

Cox, T. in Griffiths, A. (2005). The nature and measurement of work-related stress: Theory and practice. V J. R. Wilson in N. Corlett (ur.), Evaluation of human work, (3rd ed.; str. 553-572). CRC Press.

Drenovac, M. (1994). CRD - Serija psihodijagnostičkih testova [CRD Series of psychodiagnostic tests]. AKD.

EU-OSHA. (2009). Različnost delovne sile in ocena tveganja: Zagotoviti, da so vsi upoštevani: Povzetek poročila agencije [Workforce diversity and risk assessment: Ensure that everyone is considered : Report's summary] [podatkovni list]. Facts, 87. https://osha.europa.eu/sl/ publications/factsheet-87-workforce-diversity-andrisk-assessment-ensuring-everyone-covered-summary/ view

Eurofound in EU-OSHA. (2014). Psychosocial risk in Europe: Prevalence and strategies for prevention. Publications Office of the European Union. https://www.eurofound. europa.eu/sites/default/files/ef_publication/field_ef_ document/ef1443en 0.pdf

Goldhammer, F. (2015) Measuring ability, speed, or both? Challenges, psychometric solutions, and what can be gained from experimental control. Measurement: Interdisciplinary Research and Perspectives, 13(3-4), 133-164.

Green, B. F., Bock, R. D, Humphreys, L. G., Linn, R. L. in Reckase, M. D. (1984). Technical guidelines for assessing computerized adaptive tests. Journal of Educational Measurement, 21(4), 347-360.

Greene, L. S. in Williams, H. G. (1996). Aging and coordination from the dynamic pattern perspective. V A. M. Ferrandez in N. Teasdale (ur.), Changes in Sensory Motor Behavior in Aging (str. 89-131). Elsevier Science B.V.

Gulliksen, H. (1950). Wiley publications in psychology. Theory of mental tests. John Wiley and Sons.

Hill, K., Bialik, M. in Fadel, C. (2018). Psychomotor skills for the 21st century: What should students learn? Center for Curriculum Redesign. https://curriculumredesign.org/ wp-content/uploads/Psychomotor-Skills-CCR-May2018. pdf

Hockey, G. R. J. (1997). Compensatory control in the regulation of human performance under stress and high workload: A cognitive-energetical framework. Biological Psychology, 45, 73-93.

Karasek, R. A. (1979). Job demands, job decision latitude and mental strain: Implication for job redesign. Administrative Science Quarterly, 24(2), 285-308.

Karasek, R. A. in Theorell, T. (1990). Healthy work: Stress, productivity and the reconstruction of working life. Basic books.

Kisser, R., Krafack, A. in Vaughan, C. (1986). Determinationsgeräte [Determination tool]. V R. Brickenkamp (ur.), Handbuch apparativer Verfahren in der Psychologie (str. 225-249). Hogrefe.

Leonard, J. A. (1959). Tactual choice reactions: I. Quarterly Journal of Experimental Psychology, 11(2), 76-83.
Lohman, D. F. (1989). Individual differences in errors and latencies on cognitive tasks. Learning and Individual Differences, 1(2), 179-202.

Mańkowska, M., Poliszczuk, T., Poliszczuk, D. in Jochne, M. (2015). Visual perception and its effect on reaction time and time-movement anticipation in elite female basketball players. Polish Journal of Sport and Tourism, 22(1), 3-14.

Molan, M. in Arnerič, N. (2000). Struktura in vsebina psihološkega pregleda za oceno delazmožnosti [The structure of psychological examination and assessment of ability for work]. Psihološka obzorja, 9(4), 115-126.

Molan, M. in Molan, G. (2008). Model ocenjevanja v delovnem okolju [Assessment model in the work environment]. Sanitas ellabor/Ocena tveganja, 7(1), 31-44.

Musek, J. (2005). Psihološke in kognitivne študije osebnosti [Psychological and cognitive personality studies]. Znanstveni inštitut Filozofske fakultete.

Neubauer, C. A. (1990). Selective reaction times and intelligence. Intelligence, 14(1), 79-96.

Posner, M. I. in McLeod, P. (1982). Information processing models - In search of elementary operations. Annual Reviews of Psychology, 33, 477-514.

Reckase, M. D. (1989). Adaptive testing: The evolution of a good idea. Educational Measurement: Issues and Practice, 8(3), 11-15.

Schmidt, R. A. (1988). Motor control and learning: A behavioral emphasis (2nd ed.). Human Kinetics Publishers.

Schuhfried, G. (2017). Vienna test system - Determination test (Version 44 - Revision 1). Schuhfried.

Sommer, M., Heidinger, C., Arendasy, M., Schauer, S., Schmitz-Gielsdorf, J. in Häusler, J. (2010). Cognitive and personality determinants of post-injury driving fitness. Archives of Clinical Neuropsychology, 25(2), 99-117.

Škof, B. (ur.). (2019). Načrtovanje športne vadbe [Sports training planning]. Fakulteta za šport, Inštitut za šport.

Thurstone, L. L. (1937). Ability, motivation and speed. Psychometrika, 2, 249-254.

Vernon, P. A. (ur.). (1987). Speed of information-processing and intelligence. Ablex Publishing.

Vetter, M., Schünemann, L., Debelak, R., Gatscha, M., Herle, M., Mandler, G. in Ortner, T. (2015). Predicting safe driving behaviour in professional drivers: A theory-based validation of cognitive and personality tests. Zeitschrift für Verkehrssicherheit, 61(4), 222-234.

Zabukovec, V. (ur.). (2007). Psihološki vidiki preventivnih dejavnosti v prometu [Psychological aspects of preventive activities in traffic]. Znanstvenoraziskovalni inštitut Filozofske fakultete.

Zakon o varnosti in zdravju pri delu (ZVZD-1) [Occupational Safety and Health Act] (2011). Uradni list RS, št. 43/2011. https://www.uradni-list.si/glasilo-uradni-list-rs/ vsebina/2011-01-2039?sop=2011-01-2039

Prispelo/Received: 23. 3. 2020 Sprejeto/Accepted: 3. 3. 2021 


\section{Priloge}

\section{Tabela P1}

Deskriptivna statistika izvedenih preizkušenj po skupinah glede na razliko med številom predvajanih dražljajev in število odzivov

\begin{tabular}{|c|c|c|c|c|c|c|c|c|}
\hline & & $N$ & $M$ & $S D$ & $\min$ & $\max$ & $K S$ & $p$ \\
\hline \multirow{3}{*}{ DT-S1 pravilni } & 1. skupina & 84 & 250,52 & 35,76 & 162,00 & 330,00 & 0,90 & 0,400 \\
\hline & 2. skupina & 64 & 234,94 & 26,91 & 158,00 & 283,00 & 0,84 & 0,484 \\
\hline & 3. skupina & 50 & 261,02 & 30,92 & 204,00 & 327,00 & 0,64 & 0,808 \\
\hline \multirow{3}{*}{ DT-S1 napake } & 1. skupina & 84 & 16,51 & 8,78 & 3,00 & 49,00 & 1,14 & 0,148 \\
\hline & 2. skupina & 64 & 14,23 & 6,54 & 1,00 & 28,00 & 0,63 & 0,826 \\
\hline & 3. skupina & 50 & 32,20 & 12,24 & 9,00 & 69,00 & 0,58 & 0,888 \\
\hline \multirow{3}{*}{ DT-S1 izpuščeni } & 1. skupina & 84 & 10,40 & 4,90 & 3,00 & 23,00 & 1,47 & 0,027 \\
\hline & 2. skupina & 64 & 18,95 & 5,27 & 8,00 & 35,00 & 0,72 & 0,675 \\
\hline & 3. skupina & 50 & 10,52 & 6,07 & 2,00 & 31,00 & 0,84 & 0,480 \\
\hline \multirow{3}{*}{ DT-S1 RT (sek.) } & 1. skupina & 84 & 0,79 & 0,10 & 0,60 & 1,20 & 1,17 & 0,131 \\
\hline & 2. skupina & 64 & 0,78 & 0,09 & 0,59 & 1,07 & 1,02 & 0,248 \\
\hline & 3. skupina & 50 & 0,75 & 0,08 & 0,61 & 0,92 & 0,71 & 0,696 \\
\hline \multirow{3}{*}{ DT-S1 \% napak } & 1. skupina & 84 & 6,3 & 3,4 & 1,0 & 18,1 & 1,18 & 0,122 \\
\hline & 2. skupina & 64 & 5,7 & 2,5 & 0,4 & 11,3 & 0,65 & 0,786 \\
\hline & 3. skupina & 50 & 11,0 & 4,2 & 3,6 & 24,1 & 0,54 & 0,935 \\
\hline \multirow{3}{*}{ DT-S1 \% izpuščenih } & 1. skupina & 84 & 4,0 & 2,0 & 1,0 & 9,8 & 1,15 & 0,144 \\
\hline & 2. skupina & 64 & 7,7 & 2,3 & 3,3 & 14,5 & 0,75 & 0,627 \\
\hline & 3. skupina & 50 & 3,7 & 2,2 & 0,6 & 10,8 & 0,91 & 0,374 \\
\hline \multirow{3}{*}{ CRD2 čas } & 1. skupina & 84 & 45,10 & 9,61 & 28,52 & 72,69 & 1,18 & 0,126 \\
\hline & 2. skupina & 64 & 46,02 & 9,86 & 30,11 & 86,96 & 1,07 & 0,207 \\
\hline & 3. skupina & 50 & 43,16 & 7,47 & 32,36 & 66,40 & 1,02 & 0,250 \\
\hline \multirow{3}{*}{ CRD2 napake } & 1. skupina & 84 & 0,63 & 1,29 & 0,00 & 9,00 & 3,25 & 0,000 \\
\hline & 2. skupina & 64 & 0,59 & 1,11 & 0,00 & 5,00 & 2,88 & $<0,001$ \\
\hline & 3. skupina & 50 & 0,96 & 1,24 & 0,00 & 6,00 & 1,75 & 0,004 \\
\hline \multirow{3}{*}{ CRD2 RT (sek.) } & 1. skupina & 84 & 1,26 & 0,25 & 0,81 & 1,96 & 1,00 & 0,268 \\
\hline & 2. skupina & 64 & 1,29 & 0,25 & 0,86 & 2,35 & 1,17 & 0,132 \\
\hline & 3. skupina & 50 & 1,20 & 0,20 & 0,92 & 1,81 & 0,86 & 0,451 \\
\hline \multirow{3}{*}{ CRD4a čas } & 1. skupina & 84 & 35,16 & 13,15 & 17,52 & 84,78 & 1,49 & 0,024 \\
\hline & 2. skupina & 64 & 36,95 & 11,16 & 19,36 & 74,74 & 0,92 & 0,360 \\
\hline & 3. skupina & 50 & 32,21 & 8,49 & 19,19 & 59,13 & 0,80 & 0,547 \\
\hline \multirow{3}{*}{ CRD4a napake } & 1. skupina & 84 & 5,02 & 5,26 & 0,00 & 32,00 & 1,62 & 0,011 \\
\hline & 2. skupina & 64 & 4,19 & 3,63 & 0,00 & 13,00 & 1,23 & 0,097 \\
\hline & 3. skupina & 50 & 3,80 & 4,31 & 0,00 & 26,00 & 1,49 & 0,024 \\
\hline \multirow{3}{*}{ CRD4a RT (sek.) } & 1. skupina & 84 & 0,87 & 0,24 & 0,47 & 1,84 & 0,97 & 0,304 \\
\hline & 2. skupina & 64 & 0,94 & 0,25 & 0,55 & 1,74 & 0,84 & 0,478 \\
\hline & 3. skupina & 50 & 0,83 & 0,22 & 0,48 & 1,48 & 0,87 & 0,438 \\
\hline \multirow{3}{*}{ CRD4b čas } & 1. skupina & 84 & 44,87 & 13,76 & 21,93 & 83,90 & 0,84 & 0,483 \\
\hline & 2. skupina & 64 & 46,75 & 14,33 & 24,42 & 85,81 & 1,04 & 0,233 \\
\hline & 3. skupina & 50 & 41,51 & 11,27 & 26,88 & 76,29 & 0,98 & 0,289 \\
\hline \multirow{3}{*}{ CRD4b napake } & 1. skupina & 84 & 5,63 & 4,23 & 0,00 & 20,00 & 1,53 & 0,019 \\
\hline & 2. skupina & 64 & 5,06 & 4,67 & 0,00 & 23,00 & 1,47 & 0,026 \\
\hline & 3. skupina & 50 & 5,84 & 6,10 & 0,00 & 41,00 & 1,62 & 0,010 \\
\hline \multirow{3}{*}{ CRD4b RT (sek.) } & 1. skupina & 84 & 1,10 & 0,30 & 0,59 & 2,15 & 0,57 & 0,902 \\
\hline & 2. skupina & 64 & 1,16 & 0,29 & 0,68 & 2,04 & 0,68 & 0,749 \\
\hline & 3. skupina & 50 & 1,02 & 0,25 & 0,71 & 1,77 & 0,94 & 0,341 \\
\hline
\end{tabular}

Opombe: DT-S1 - Preizkus razpršene pozornosti in motoričnega odzivanja, CRD2 - Preizkus enostavne orientacije v polju,

CRD4a - Preizkus enostavne vidno motorične koordinacije, CRD4b - Preizkus diferencialne vidno motorične koordinacije. 